Original Research

\title{
Land Cover Changes in Natura 2000 Areas Located in Suburban Zones: Planning Problems in the Context of Environmental Protection
}

\author{
Anna Gałecka-Drozda ${ }^{1 *}$, Elżbieta Raszeja ${ }^{2}$, Magdalena Szczepańska ${ }^{3}$, \\ Agnieszka Wilkaniec ${ }^{1}$ \\ ${ }^{1}$ Department of Landscape Architecture, Poznań University of Life Sciences, Poznań, Poland \\ ${ }^{2}$ Department of Architecture and Urban Planning, Faculty of Architecture and Design, \\ The University of the Arts in Poznań, Poznań, Poland \\ ${ }^{3}$ Institute of Socioeconomic Geography and Spatial Planning, Adam Mickiewicz University in Poznań, \\ Poznań, Poland
}

Received: 18 September 2017

Accepted: 29 November 2017

\begin{abstract}
The aim of the article was to identify changes in the structure of land use and land cover in the context of spatial planning problems. The research was conducted on valley areas protected under the Natura 2000 programme and that are located within the zone of influence of a big city. The researchers analysed local planning documents to see whether they were in agreement with the aims of the protection programme. The Natura 2000 areas located in the Commune of Stęszew, Poznań County were chosen for a case study. The article describes recurrent problems and phenomena that are typical of the protected areas and that are simultaneously affected by the pressure of urbanisation. GIS tools were used to make a comparative analysis of six categories of land use forms in three research periods and to calculate the indicator of land cover variance. Since the 1980s, the areas under study have been affected by changes in land use. They have been manifested by a higher forestation rate, increasing numbers of developed areas, and a decrease in farmland area. The percentage of other components of the land cover structure has not changed much. In view of environmental protection, the changes proposed in spatial plans are a matter of special concern. The territory under analysis is characterised by a very high land cover variance indicator referring to the developed area, whereas the indicators referring to farmland and wetland areas are negative. It is particularly difficult to apply the rule of sustainable development in the areas. The protection of natural values and the developmental needs of the commune stand in opposition to each other and cause spatial planning conflicts.
\end{abstract}

Keywords: land use, Natura 2000, suburban zone, environment protection, spatial planning

*e-mail: anna.galecka@up.poznan.pl 


\section{Introduction}

Since 1992 the creation of a network of Natura 2000 areas has been an essential nature conservation task in all member-states of the European Union. In 2004, this form of protection was introduced into Polish legislation [1]. Natura 2000 areas complemented and partly converged with the national system of protected areas [2-3]. At present, more than a fifth of the area of Poland is covered by this form of protection. Different activities taken in Natura 2000 areas or in their direct neighbourhood are not always in agreement with nature conservation, or sometimes they even stand in opposition to it (agriculture, forestry, tourism, services, and production). It is very difficult to manage these areas, especially in the suburban zone, because it is necessary to reconcile protective actions with the existing land use forms and investment needs. Apart from that, it is necessary to maintain local ecological corridors connecting natural areas to ensure the consistency of the network. Therefore, it is necessary to adopt a holistic approach to spatial planning and management in order to maintain biodiversity, preserve or restore ecological coherence and create sustainable landscape, simultaneously allowing for local cultural factors and current socioeconomic needs [4-8].

Spatial planning is an activity equipped with the necessary instruments to achieve spatial order and to indicate trends of sustainable development. The authors of reference publications in different countries point to the connection between the spatial policy and changes in land use in suburban zones [9-10]. The spatial policy and regulations affect the state of the environment [11], preservation of open spaces [12], and the spatial structure and distribution of key elements concerning development [13]. Many authors of Polish reference publications describe spatial planning as an essential tool used for the creation of space, landscape, and the environment. Simultaneously, they indicate the imperfection of the Polish spatial planning system - especially the low effectiveness of planning tools and the fragmentation of areas covered by spatial plans [14-18]. It is particularly noticeable in the suburban zone, where spatial planning should be used to control dynamic urbanisation as well as functional and spatial transformations that endanger the quality of the natural and cultural environment [19-22].

The authors of this article investigated the aforementioned problems in their study on valley areas located in the Commune of Stęszew and protected under the Natura 2000 programme. The aim of the article was to assess the dynamics and scale of changes and their impact on protected areas that have taken place in these areas in the last 30 years as well as the future changes resulting from the spatial planning documentation. We made a comparative analysis of the changes in three time periods. Spatial conflicts were analysed and assessment of the spatial policy of the local government in terms of implementation of nature conservation goals was made. The authors analysed the consistency of provisions in local planning documentation (i.e., "Study of the conditions and directions of the spatial management of a commune" and local spatial management plans). The initial observations led to the research hypothesis that the provisions concerning the protection of natural values usually have a declarative nature, whereas in practice the implementation of land use plans is usually in conflict with nature conservation goals.

\section{Study Area and Methods}

\section{Spatial Structure and Natural Resources}

The study was conducted on the commune of Stęszew located in the suburban zone of Poznań, where the heavy pressure of investments is a threat to natural values and makes it difficult to protect these values in spatial planning. The problems and phenomena are typical of the areas whose natural values are protected but which are simultaneously influenced by intensive urbanisation. Stęszew is located in southern Poznań County (Fig. 1) and is separated from the city limits of Poznan by the communes of Mosina and Dopiewo. Trunk road No. 5, which crosses the commune, is an axis for the development of investments. Stęszew is the main residential centre in the commune.

The research was conducted to the east of the commune, where three areas of the Natura 2000 network are located: Wielkopolska Refugium PLH300010, Rogalin Refugium PLB300017, and Będlewo-Bieczyny PLH300039 [23]. They occupy an area of $45 \mathrm{~km}^{2}$, i.e., about $26 \%$ of the commune area (Fig. 2). Wielkopolska Refugium is the largest habitat. It occupies an area of $8,427.12$ ha. In the southeast it is bordered by the Samica Stęszewska River valley and lakes Tomickie, Wielkowiejskie, Witobelskie, and Dymaczewskie.

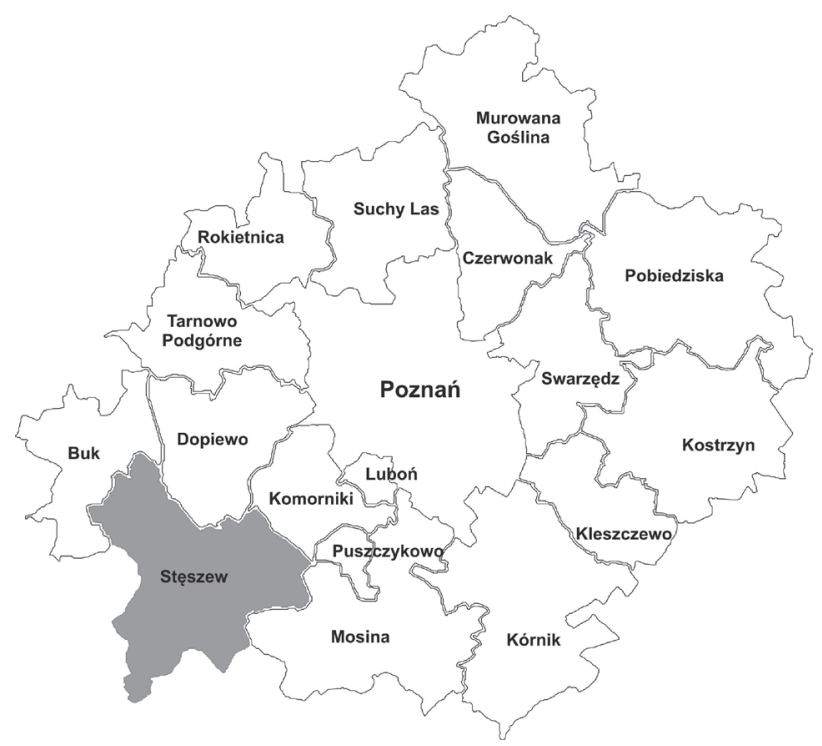

Fig. 1. The commune of Stęszew in the administrative division of Poland: a) Poland/voivodeships; b) Greater Poland/counties; c) Poznań county/communes (compiled by the authors). 


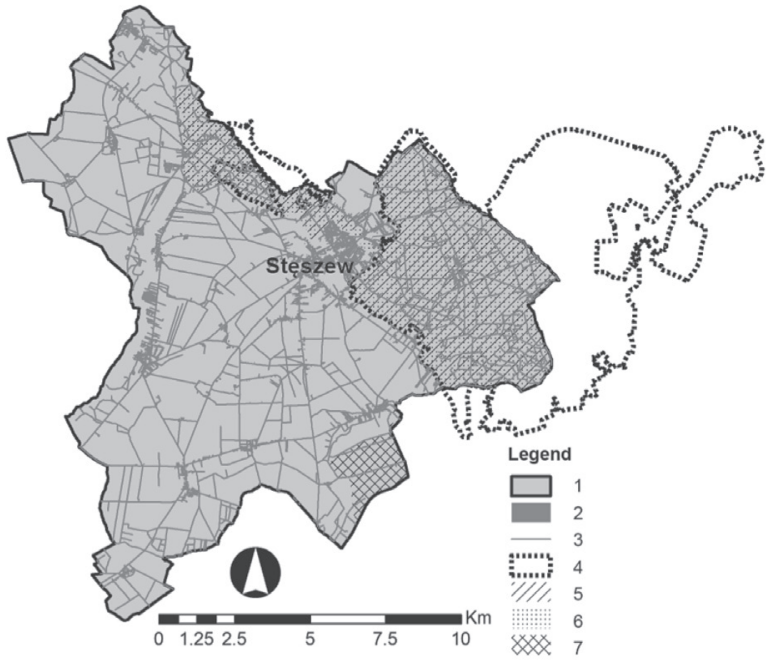

Fig. 2. Natura 2000 areas in the Commune of Stęszew: 1 - the Commune of Stęszew, 2 - developed areas, 3 - roads, 4 - Wielkopolska National Park boundaries, 5 - Rogalin Refugium Natura 2000 area, 6 - Wielkopolska Refugium Natura 2000 area, 7 - Będlewo-Bieczyny Natura 2000 area (compiled by the authors).

The main part of Wielkopolska Refugium is located in the northeast of the commune. It is covered by forests in Wielkopolska National Park and the village of Trzebaw. The area is characterised by high biodiversity as there are 17 types of habitats. There is a bird habitat of $21,763.12$ ha in Rogalin Refugium. The area mostly covers the same places as Wielkopolska Refugium, except a small part, which is in the direct neighbourhood of the town of Stęszew. The place is one of the most important habitats of black terns and middle spotted woodpeckers

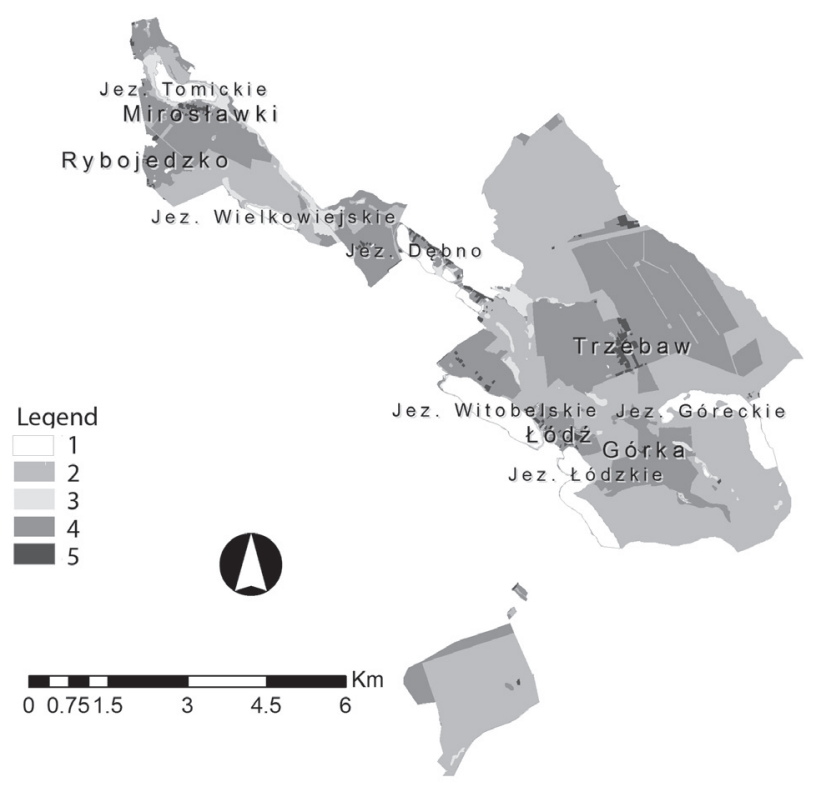

Fig. 3. Major topographic elements within the area under study: 1 - open waters, 2 - forests, 3 - wetlands, 4 - farmlands, 5 - built-up areas (compiled by the authors). in Poland. Będlewo-Bieczyny is the smallest (751.98 ha) Natura 2000 area in the Commune of Stęszew. It does not have direct spatial connection with other forms of nature conservation. It is chiefly covered by forests near the Mosina Canal.

The Natura 2000 areas in the Commune of Stęszew occupy part of the Samica Stęszewska River valley. The river flows from the northwest toward the southeast, running through the following ribbon lakes: Lake Tomickie in the north, and lakes Witobelskie and Dymaczewskie in the south (Fig. 3). Lake Góreckie, which is the middle of the forest in the east of the area under study, and Lake Dębno, surrounded by built-up areas between the town of Stęszew and the village of Dębno, are important elements of the natural environment. Another element is the valley of the Trzebawka River, which is a small left-bank tributary of the Samica Stęszewska River.

The village of Trzebaw is the largest inhabited community situated in the Natura 2000 area in the Commune of Stęszew. The village is surrounded by a large complex of farmlands. The village of Dębno is the most urbanised part of this area. It breaks the ecological continuity of protected areas. Other major settlements are the village of Mirosławki, which is situated in the north on Lake Tomickie, and the village of Łódź, which is situated between lakes Witobelskie and Dymaczewskie. There are dispersed developments in other areas.

The GIS environment was used to analyse changes in the land cover. The database of topographic objects was the input material. The first stage of the research involved analysis of land use before establishment of the Natura 2000 network. The year 1989 was assumed as the comparative period, because it marked the beginning of changes in the political system in Poland, which resulted in intensive spatial transformations. The analysis was based on topographic maps scaled 1:25,000 published between 1962 and 1989. Although the maps spanned a few decades, we assumed that the scale of transformations in that period did not have significant influence on the results of the study. At the second stage of the research, available ortophotographs were used to identify the current land cover (geoportal. gov.pl). The third stage involved a forecast analysis based on the study of the conditions and directions of the spatial management of the commune of Stęszew of 2014. The study is not a local legal act, but it is the only document that covers the whole area of the commune and it enables forecasts of future land use. It is necessary to stress that the terms "land use" and "land cover" have different meanings. The study expresses spatial policy of local municipalities, determining possibilities of land use and land allocation, terms of spatial arrangement, and building parameters. All listed provisions of the study may cause the changes in land cover that were investigated by the authors. The research involved identifying the trends and dynamics of changes in the land cover, divided into the following six categories: forests and areas with trees, 
farmlands, wetlands, developed areas, roads, and open waters. The maps from 1962-1989 were imported to the GIS software from the Web Map Service (WMS). The drawing in The study showing spatial development trends was added to the map content and georeferenced. Then the area was measured according to the aforementioned typology for the research periods assumed. The land cover variance indicator was calculated according to the formula below. The input data referred to 1989 (Ia) were compared to data of current area $(\mathrm{Ca})$ or to data of forecast area $(\mathrm{Fa}-$ based on a study of conditions and directions of the spatial management of a commune). Use of the indicator $\left(\mathrm{I}_{\text {lcv }}\right)$ enable us to define the scale of current and future changes in land cover. Results of the indicator calculations are presented in Table 1.

$$
I_{l c v}=\left(\frac{C a \text { or } F a}{I a} * 100 \%\right)-100 \%
$$

...where $\mathrm{I}_{\mathrm{lcv}}$ is land cover variance indicator $(\%), \mathrm{Ca}$ is current area (ha), $\mathrm{Fa}$ is forecast area (ha) (based on a study of conditions and directions of the spatial managemant of a commune), and Ia is input area (ha) (data from 1989).

Before analysing changes in land cover, the researchers reviewed the current documents concerning nature protection and spatial planning in the commune: the draught of the Wielkopolska National Park Protection Plan (2013), the Study of the Conditions and Directions of the Spatial Management of the ommune of Stęszew (2014), and local spatial management plans. The documents were analysed in terms of the consistency of their provisions and the forecast consequences of implementation of these provisions for Natura 2000 areas and protection of natural values.

\section{Results}

\section{Spatial Planning Situation \\ Wielkopolska National Park - Draught Protection Plan}

Detailed procedures, including the management of Natura 2000 areas, are prepared for each area individually in the form of a protection plan or a plan of protective tasks. No protection plans have been prepared for the areas under study. Wielkopolska National Park is the superior form of nature conservation. In 2013, a protection plan was prepared for this area [24]. Appendix 7 in this document (p. 95) includes all provisions concerning new studies of the conditions and directions of the spatial management of a commune and trends in spatial development concerning communes located in Wielkopolska National Park, local spatial management plans, and the spatial development plan for the voivodship. The provisions mostly concern the elimination and limitation of external and internal threats to the park. They also list the actions that need to be taken to maintain or restore the natural habitats as well as the plant and animal species in Natura 2000 areas. There are detailed provisions concerning the development of protected areas. The location of buildings at a shorter distance than $30 \mathrm{~m}$ away from the boundaries of Wielkopolska National Park and in wildlife corridors designated by plan is prohibited. Forests and areas with trees are protected by the order to preserve them and to extend their areas and spatial continuity if possible. Tall vegetation is also protected. Logging is allowed only in justified cases, in places where buildings will be constructed and the ground needs to be hardened. It is necessary to prepare a local plan for the village of Trzebaw to clearly define the spatial development method.

Table 1. Area and percentage share of different types of land use and cover in Natura 2000 areas in the Commune of Stęszew during different periods, and the variance indicators.

\begin{tabular}{|c|c|c|c|c|c|c|c|c|}
\hline & \multicolumn{2}{|c|}{$1980 \mathrm{~s}^{*}$} & \multicolumn{3}{c|}{ Current situation (2017) } & \multicolumn{3}{c|}{ Forecast } \\
(based on Land Use Plan)
\end{tabular}

*input data: the areas are used as reference values for other periods under analysis 


\section{Study of the Conditions and Directions of the Spatial Management of the Commune of Stęszew}

The current Study [25] repeatedly emphasises the fact that the commune has outstanding natural values that need to be protected. The document lists the rules of the spatial policy, where it is necessary to protect the commune's natural potential and manage its areas rationally [ibidem; p. 98]. The protection and preservation of natural values is listed on top of all trends of the commune's development [ibidem, p. 99]. The development of housing is listed as the second most important trend. According to the study, actions aimed at protection of the national park and Natura 2000 areas should take priority in the eastern part of the commune, and it is necessary to maintain the continuity of ecological corridors, minimise collisions between humans and the environment, maintain and increase the area of forests, and promote organic farming [ibidem, p. 99]. According to the study, in order to protect the natural and scenic values, farmlands and unarranged green spaces should not be built up. This particularly applies to the areas located northwest of Lake Tomickie, which are of particular natural and scenic value and which should be protected by new forms of nature conservation [ibidem, p. 110]. The study specifies the course of local "wildlife corridors" and the "zone of natural value", which should be covered by new forms of nature conservation. Apart from the aforementioned a)

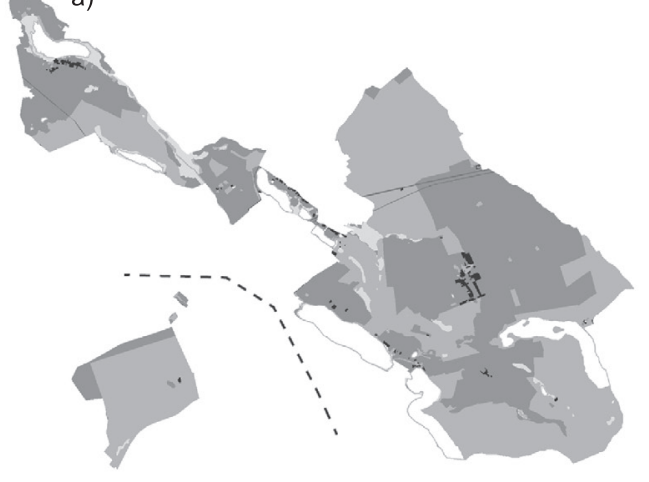

b)

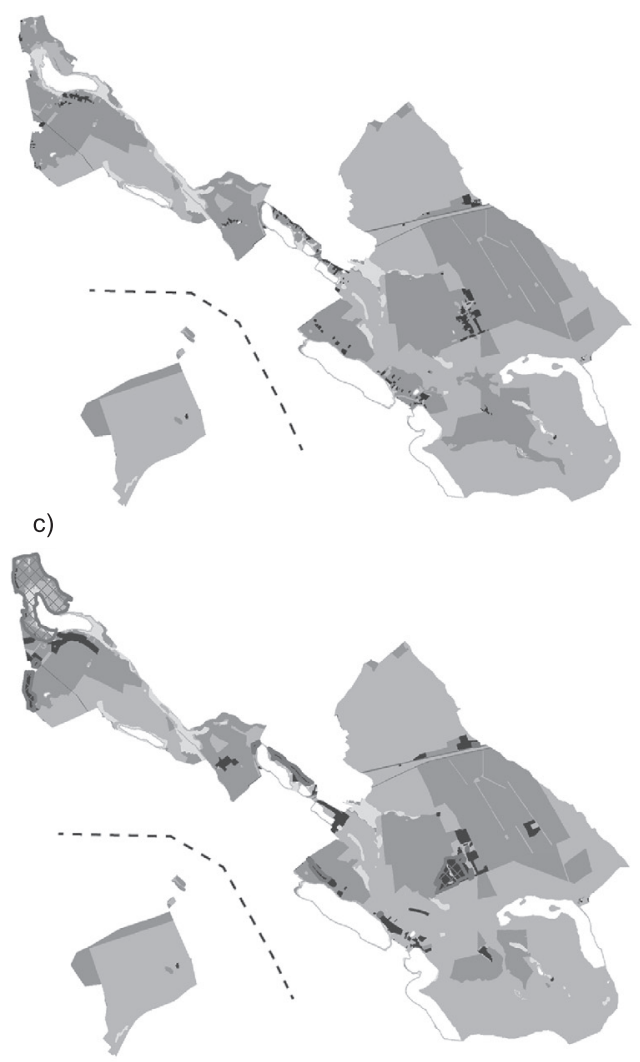

a)

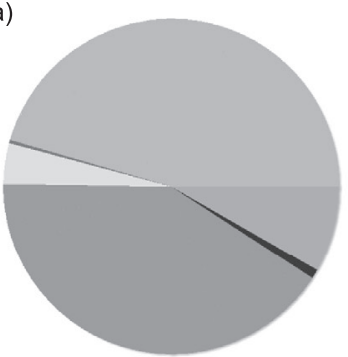

b)

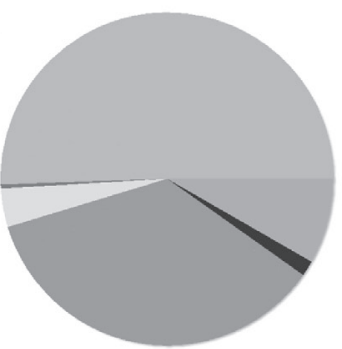

c)
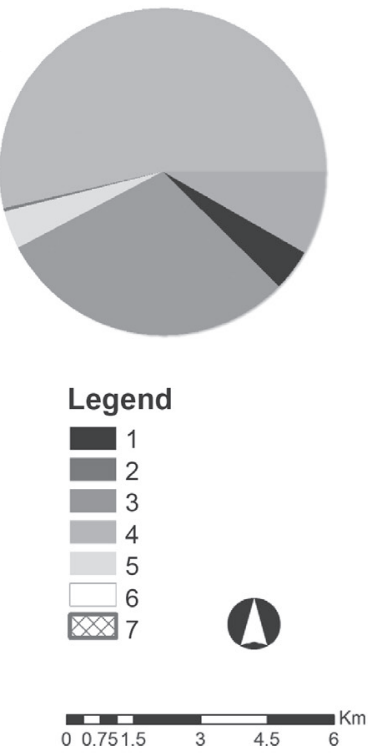

Fig. 4. Changes in the land cover in Natura 2000 areas in the Commune of Stęszew: A - the 1980s, B - the current situation (2017), $\mathrm{C}$ - a forecast based on the Land Use Plan; 1 - wetlands, 2 - roads, 3 - built-up areas, 4 - forests and areas with trees, 5 - farmlands, 6 - open waters, 7 - areas covered by local spatial development plans (compiled by the authors). 
protective provisions, the document also includes regulations referring to the use of these areas and specifies new sites to be built up.

\section{Local Spatial Management Plans}

Some new construction sites listed in the study of the conditions and directions of the spatial management of the commune of Stęszew are located in Natura 2000 areas and were included in local spatial management plans (Fig 4-c). The largest area to be built up is located in the village of Trzebaw. Residential buildings are planned to be built in an area of 29 ha, which is located between the existing buildings in the village and the forest complex [26]. There are other small sites where residential buildings with shops and services are to be built. They are located in the villages of Dębno, Łódź, and Witobel. The buildings to be constructed in the areas included in local spatial management plans will be dispersed. They may disorder the normal function of the natural environment and disrupt the continuity of ecosystems.

Only one plan covering the area under analysis has a protective nature. It refers to the villages of Tomice and Mirosławki [27]. The plan was drawn up to maintain the current use of farmlands and forests on Lake Tomickie and in the Samica Stęszewska River valley, and to preserve their high natural and scenic values. However, the plan triggered protests of the owners of plots located in these areas, who wanted decisions concerning the conditions of spatial development in their estates. In spite of conflicts and lengthy legal procedures the plan was approved [28].

\section{Assessing Land Cover Changes}

The qualitative research included analyses of the spatial distribution of transformations, which were presented graphically (Fig. 4). The results of quantitative research were compared in a table (Table 1) that included the area and percentage share of different forms of land use and land cover and the indicator of variance of changes during the selected periods.

In the second half of the $20^{\text {th }}$ century the areas under study were mostly used for farming or they were covered by forests. There was a similar percentage of forests and farmlands, i.e., $45.5 \%$ and $41 \%$, respectively. Other forms of land cover amounted to $14 \%$ in total. There were buildings in about 42 ha, i.e., only in $0.93 \%$ of the total area. Part of the area under analysis has been protected since 1957, when Wielkopolska National Park was established. Probably, as a result, investments were stopped in this area, unlike in the places located outside the park.

Changes in land use have been taking place since the 1980s. They have been manifested by a higher forestation rate and increasing number of developed areas, mostly in the south of the area under study. Since the 1980s the share of forests and areas with trees has increased from
$45.49 \%$ to $50.59 \%$. The forestation rate has increased noticeably in Wielkopolska National Park near the villages of Górka and Łódź, between Lake Góreckie and Lake Dymaczewskie. The share of developed areas has increased from $0.93 \%$ to $1.48 \%$. New built-up areas appeared to the west of the village of Trzebaw. There were dispersed buildings between Lake Witobelskie and Lake Dymaczewskie and along the northwestern shore of Lake Witobelskie. There was an increase in the density of buildings in the village of Dębno, in the direct neighbourhood of the Samica River valley, and in the village of Kraplewo. The enlargement of forests and built-up areas caused the farmland area to decrease from $41.02 \%$ to $35.5 \%$. The areas of other components of the land cover (open waters, wetlands) have not changed and amount to 375 ha in total $(7.8 \%)$.

The provisions of the study show that we can expect further development in the commune. There will be higher density of buildings and the village will mostly develop along major roads (Fig. 4c). The most residential areas will appear in the village of Trzebaw. Apart from the condensation of the current developments, a new area of about 24 ha in the southwest of the village will be built up. New investments will result in more than a double increase in the built-up area. The area of new developments in Natura 2000 areas in the Commune of Stęszew may increase three times (from 67 to $184 \mathrm{ha}$ ). The expected increase in the residential and serviceproviding function in the village of Dębno is a matter of the greatest concern because it is a bottleneck in the system of ecological connections between the protected areas. We can expect a high increase in the anthropogenic pressure exerted on the valley of lakes Dębno, Bochenek, and Lipno. The implementation of provisions of the study will also have positive consequences. The area covered by trees, especially in the form of unarranged green space, is expected to increase mostly in the national park.

The indicator of variance in changes spanning the period from the late 1980s until now is important for assessing changes in the land use and land cover. It is also important for the assessment of future transformations that are expected to happen after the study has been implemented. The area under study is characterised by positive values of the forestation rate variance indicator, i.e., $11.21 \%$ and $17.81 \%$ (referring respectively to the periods under analysis) and very high values of the built-up area variance indicator, i.e., $58.3 \%$ and $334.51 \%$. The farmland area variance indicator is negative, i.e., $-13.45 \%$ and $-27.03 \%$, respectively. There were minimal values of the wetland area variance indicator ( $-3.28 \%$ in both periods). There were no changes in the areas of open waters and roads (Table 1).

\section{Discussion}

The nature conservation goals listed in the draught of the Wielkopolska National Park Protection Plan should 
determine trends in the development of the research area. However, analysis of spatial planning documents shows that although the conservation and preservation of natural values is declared to be the most important trend in the development of the commune, in practice the development of the residential function tends to predominate. The implementation of both development trends may stand in opposition to each other. As results from the forecast of potential changes in land use, the provisions of the study of the conditions and directions of the spatial management of the Commune of Stęszew stand in opposition to the draught of the Wielkopolska National Park protection plan. There is disagreement concerning the location of new buildings and continuity of local ecological connections. Many authors indicate that the fragmentation of areas covered by the local spatial management plan is one of major reasons for the imperfection of the spatial planning system [4, 14$15,17-18]$. This observation was also confirmed in this study. According to the draught of the Wielkopolska National Park protection plan, it was necessary to prepare a local spatial development plan for Trzebaw. When the plan was prepared, it approved developments in the park. New buildings were allowed to be constructed on the edge of the forest. It is against nature conservation. However, on the other hand, effective spatial planning regulations can stop the pressure for investments in areas of natural value, as was done in the local spatial development plans for the villages of Tomice and Mirosławki. The local government of the commune was determined to guarantee that the areas of particular value were effectively protected from degradation, and a protective plan was successfully approved.

The effectiveness of spatial planning is to a certain extent limited by the very nature of this practice. There may be problems not only in the Polish legal system but also in other systems. The sector-dependent character of spatial planning decisions is listed as one of the primary problems. Decisions are taken individually and are not interrelated [9]. The problem could be solved by an integrated approach to spatial planning. This tool would integrate different sectors and scales [29]. Another common problem is failure to make a detailed analysis of the phenomena and trends in spatial transformations in a particular area before making spatial planning decisions. The chance for effective actions could be increased by setting the trend and dynamics of transformations, identifying the factors causing changes and implementing adequate methods aiding spatial planning decisions [30-31]. Preliminary analyses should be made before decisions. Otherwise, there may be a wrong diagnosis, which will result in ineffective or even harmful actions. The spatial policy in nature protection areas does not always result in positive effects [11], as can be seen in the case under study.

These spatial planning problems are typical of suburban areas, which are affected by urban sprawl. The extension of built-up areas, which may take place when the study of the conditions and directions of the spatial management of a Commune is implemented, will have numerous negative consequences for the natural environment, such as the loss of farmland and open spaces, higher consumption of energy, and emission of exhaust gases [32, 34-35]. Apart from that, investments in new areas will result in landscape fragmentation, changes in the functioning of ecosystems in areas of natural value, and lower quality of services provided in these areas [33, 35-36]. In consequence, many habitats may be lost and the extinction of species may be accelerated [37]. This will result in the loss of objects protected in the Natura 2000 areas.

The research results do not provide a clear answer to the hypothesis posed in the introduction to this article. On the one hand, when we compare the scale of changes in the developed areas and the forecasts, the hypothesis about the declarative character of provisions concerning nature protection in spatial planning documentation seems to be confirmed. On the other hand, the increase in the forestation rate in the area under study should be regarded as a positive effect. It proves the protective dimension of the study and contradicts the research hypothesis. Numerous studies show that a network of areas with trees improves the habitat conditions and reduces the spread of pollution - which is particularly important in an agricultural landscape [38-39]. The extension of built-up and afforested areas will cause a considerable loss of farmland. On the one hand, this effect could be positive to a certain extent, because intensive farming is one of the greatest threats to biodiversity [40]. However, the concept of organic farming shows that it is possible to combine effective farming and preserve natural resources [41]. Reports indicating the decreasing area of wetlands are a matter of particular concern in the context of the Ramsar Convention, and actions have been taken to protect the climate, the quality of surface and underground waters, and habitats. However, other countries' experience shows that it is possible to restore these ecosystems [42].

The fact that Wielkopolska National Park is part of the area under study has a positive influence on the maintenance of the protected areas. It is necessary to continue research on other Natura 2000 areas, which are subject to investment pressure but are not protected by other forms of nature conservation. This article presents statistical data concerning changes in the land cover. Further research on the area is recommended to analyse the distribution of areas with trees, which function as biogeochemical barriers, and a system of local ecological connections.

\section{Conclusions}

Spatial planning plays an important role in the management of areas protected under the Natura 2000 programme. However, the practical implementation of land use plans may have various consequences. This fact was confirmed by analysis of spatial planning 
documentation in the Commune of Stęszew and comparison of land use plans with the actual variance in land cover in that area. The provisions included in land use plans result both in rational management of protected areas and in actions which stand in opposition to nature conservation. Many provisions in the study of the conditions and directions of the spatial management of the Commune of Stęszew may limit developments in protected areas, which are the greatest threat for them at the moment. The provisions included in local spatial development plans may play a similar role, as was shown in the examples given in this article. On the other hand, land use plans also include numerous provisions that may increase the built-up area and cause further sprawl of developments in Natura 2000 areas. The research shows that there are ambivalent consequences of spatial planning decisions and that there is no consequence in the implementation of nature conservation goals.

The original research findings and discussion on the problem led to the following general conclusions. The tendencies and scale of transformations justify the need to lead a consequent spatial policy. It should be manifested by consistent and unequivocal provisions in spatial planning documentation. It is noteworthy that the implementation of these provisions will result in changes in land use and land cover. In consequence, they will affect not only the function of ecosystems and the state of the environment but also the quality of space, landscape, and inhabitants' lives. Therefore, spatial planning in Natura 2000 areas should be based on integrated implementation of all goals of sustainable development.

\section{Conflict of Interest}

The authors declare no conflict of interest.

\section{References}

1. NATURE PROTECTION ACT, 2004, Official Journal 2016 No.0 Pos. 2134 with amendments, 2004 [In Polish].

2. THE BIRDS DIRECTIVE - Directive 2009/147/EC of the European Parliament and of the Council of 30 November 2009 on the conservation of wild birds - previously: the Council Directive 79/409/EEC of 2 April 1979 on the conservation of wild birds, 2009.

3. THE HABITATS DIRECTIVE - Council Directive 92/43/ EEC of 21 May 1992 on the conservation of natural habitats and of wild fauna and flora, 1992.

4. RASZKA B. The Warta River Ravine in Poznań in the Planning of Ecosystems. Bogucki Wydawnictwo Naukowe, Poznań, 2003 [In Polish].

5. WU J. Landscape of culture and culture of landscape: does landscape ecology need culture? Landscape Ecology, Vol. 25 (8), 1147, 2010.

6. LAI S., LEONE F., ZOPPI C. Land cover changes and environmental protection: A study based on transition matrices concerning Sardinia (Italy). Land Use Policy, 67, 126, 2017.
7. VLAMI V., KOKKORIS I. P., ZOGARIS S., CARTALIS C., KEHAYIAS G., DIMOPOULOS P. Cultural landscapes and attributes of "cultureless" in protected areas: An exploratory assessment in Greece. Science of the Total Environment, 595, 2293, 2017.

8. GEITZENAUER M., BLONDET M., DE KONING J., FERRANTI F., SOTIROV M., WEISS G., \&WINKEL G. The challenge of financing the implementation of Natura 2000 - Empirical evidence from six European Union Member States. Forest Policy and Economics, 2017.

9. GANT R.L., ROBINSON G.M., FAZAL S. Land-use change in the 'edgelands': Policies and pressures in London's rural-urban fringe. Land Use Policy, 28 (1), 266, 2011.

10. MARUANI T., AMIT-COHEN I. Patterns of development and conservation in agricultural lands - The case of the Tel Aviv metropolitan region 1990-2000. Land Use Policy, 27, 671, 2010.

11. PETROSILlO I., ZACCARELLI N., SEMERARO T., ZURLINI G. The effectiveness of different conservation policies on the security of natural capital. Landscape and Urban Planning 89, 49, 2009.

12. MARUANI T., AMIT-COHEN I. Characteristics of developers and their relations to open space conservation. Land Use Policy, 28, 887, 2011.

13. ALTES W.K.K., VAN RIJ E. Planning the horticultural sector: Managing greenhouse sprawl in the Netherlands. Land Use Policy, 31, 486, 2013.

14. POLES' LIVING SPACE. Report. Concept and Coordination J. Sepioł. Stowarzyszenie Architektów Polskich SARP, Warsaw, 2014 [In Polish].

15. RASZEJA E. Landscape Protection in the Process of Rural Transformations. Wydawnictwo Uniwersytetu Przyrodniczego w Poznaniu, Poznań, 2013 [In Polish].

16. HEŁDAK M., RASZKA B. Evaluation of the Local Spatial Policy in Poland with Regard to Sustainable Development. Polish Journal of Environmental Studies, 22 (2), 3952, 2013.

17. KOWICKI M. Dispersed Developments in Lesser Poland and the Crisis of Creativity in Spatial Planning Documentation. Wydawnictwo Politechniki Krakowskiej, Kraków, 2014 [In Polish].

18. SZULCZEWSKA B. Spatial Planning as an Instrument of Implementation of Ecological Networks: between the Theory and Practice. Problemy Ekologii Krajobrazu, 14, 54, 2014 [In Polish].

19. MIZGAJSKI A. (ed.), Natural Resources and Their Protection in the Poznań Agglomeration. Biblioteka Aglomeracji Poznańskiej Nr 2, Bogucki Wydawnictwo Naukowe, Poznań, 2010 [In Polish].

20. RASZEJA E., WILKANIEC A., DE MEZER E. Landscape and Rural Cultural Heritage in the Poznań Agglomeration. Biblioteka Aglomeracji Poznańskiej No. 3, Bogucki Wydawnictwo Naukowe, Poznań, 2010 [In Polish].

21. ŻARSKA B. Protection of the Structure and Functioning of Particularly Valuable Natural Landscapes. Problemy Ekologii Krajobrazu 21, 45, 2014 [In Polish].

22. SZCZEPAŃSKA M., WILKANIEC A. Local Spatial Development Plan and Rural Space Creation - a case study. Folia Geographica Socio-Oeconomica 28, 83, 2017 [In Polish].

23. ENVIRONMENTAL PROTECTION PROGRAM FOR THE STESZEW COMMUNE 2011-2014 with a perspective until 2018. Mayor of Stęszew, Stęszew, 2011 [In Polish].

24. A DRAUGHT REGULATION OF THE MINISTER OF THE ENVIRONMENT ON THE PROTECTION PLAN 
FOR WIELKOPOLSKA NATIONAL PARK, 2013 [In Polish].

25. THE STUDY OF THE CONDITIONS AND DIRECTIONS OF THE SPATIAL MANAGEMENT OF THE COMMUNE OF STĘSZEW, Town Council Resolution No. XXXIX/333/2014 of 11 September 2014, 2014 [In Polish].

26. RESOLUTION No. XXIII/226/2008 of the Town Council of the Commune of Stęszew of 29 December 2008 on: local spatial development plan for single-family and residential houses in part of the village of Trzebaw in the Commune of Stęszew, 2008 [In Polish].

27. RESOLUTION No. XIV/113/2011 of the Town Council of the Commune of Stęszew of 28 December 2011 on local spatial development plan in part of the villages of Tomice and Mirosławki located in geodesic districts of Tomice, Mirosławki and Rybojedzko in the Commune of Stęszew, 2011 [In Polish].

28. RASZEJA E., WILKANIEC A, SZCZEPAŃSKA M. Management of landscape resources as an element of sustainable development of communes in the Poznań agglomeration - declarativeness of assumptions vs realities of spatial policy. Space \& Form, 29, 135, 2017.

29. SCOTT A.J., CARTER C., REED M.R., LARKHAM P., ADAMS D., MORTON N., WATERS R., COLLIER D., CREAN C., CURZON R., FORSTER R., GIBBS P., GRAYSON N., HARDMAN M., HEARLE A., JARVIS D., KENNET M., LEACH K., MIDDLETON M., SCHIESSEL N., STONYER B., COLES R. Disintegrated development at the rural-urban fringe: Re-connecting spatial planning theory and practice. Progress in Planning, 83, 1, 2013.

30. NENKOVIC-RIZNIC M., VLADICARISTIC V., MILIJIC S. Integration of Strategic Environmental Assessment and Environmental Social Impact Assessment into Strategic Territorial Planning: Lessons Learned from Two Cases of Tourism Destinations In Protected Areas. Polish Journal of Environmental Studies, 25 (3), 1353, 2016.

31. LEONE F., ZOPPI C., Participatory processes and spatial planning. The Regional Landscape Plan of Sardinia, Italy. Franco Angeli Edizioni, 2016.

32. HENNIG E.I., SCHWICK C., SOUKUP T., ORLITOVÁ E., KIENAST F., JAEGER J.A. Multi-scale analysis of urban sprawl in Europe: Towards a European de-sprawling strategy. Land Use Policy, 49, 483, 2015.
33. DUPRAS J., MARULL J., PARCERISAS L., COLL F., GONZALEZ A., GIRARD M., TELLO, E. The impacts of urban sprawl on ecological connectivity in the Montreal Metropolitan Region. Environmental Science \& Policy, 58, 61, 2016.

34. MOSAMMAM H.M., NIA J.T., KHANI H., TEYMOURI A., KAZEMI M. Monitoring land use change and measuring urban sprawl based on its spatial forms: the case of Qom city. The Egyptian Journal of Remote Sensing and Space Science, 20 (1), 103, 2017.

35. ESTOQUER.C., MURAYAMA Y. Quantifying landscape pattern and ecosystem service value changes in four rapidly urbanizing hill stations of Southeast Asia. Landscape Ecology, 31, 1481, 2016.

36. LI H., PENG J., YANXU L., YI'NA HU. Urbanization impact on landscape patterns in Beijing City, China: A spatial heterogeneity perspective. Ecological Indicators 82, 50,2017

37. LISON F., SANCHEZ-FERNANDEZ D. Low effectiveness of the Natura 2000 network in preventing land-use change in bat hotspots. Biodiversity and Conservation, 1, 2017.

38. RYSZKOWSKI L. The Significance of Functional Landscape Analysis for Spatial Planning. In: Environmental Protection in Spatial Management, Ed. L. Ryszkowski, A. Kędziora. Wyd. Prodruk, Poznań: 49, 2005 [In Polish].

39. SZAJDAK L., ŻYCZYŃSKA-BAŁONIAK I., JASKULSKA R., SZCZEPAŃSKI M. Changes of the concentrations of dissolved chemical compounds migrating into ground water through biogeochemical barriers in an agricultural landscape. Oceanological and Hydrobiological Studies, 38 (4), 109, 2009.

40. SANTRUCKOVA M., DOSTALEK J., DEMKOVA K. Assessing long-term spatial changes of natural habitats using old maps and archival sources: a case study from Central Europe. Biodiversity and conservation, 24, 1899, 2015.

41. VIJAYAN R. Eco-farming: relevance and rewards. International Journal of Farm Sciences. 6 (4), 67, 2017.

42. VERHOEVEN J. T. Water-quality issues in Ramsar wetlands. Marine and Freshwater Research, 65 (7), 604, 2014. 
